\title{
PENERAPAN MODEL PROBLEM BASED LEARNING UNTUK MENINGKATKAN HASIL BELAJAR PADA SUBTEMA BANGGA TERHADAP DAERAH TEMPAT TINGGALKU
}

\author{
Yunida Devitasari ${ }^{1)}$, Rais Hidayat ${ }^{1)}$, Dadang Kurnia ${ }^{1)}$ \\ ${ }^{*}$ Universitas Pakuan, Kota Bogor, Indonesia \\ e-mail korespondensi : dadang1859040@unpak.ac.id
}

diterima: 03 Juli 2018; direvisi: 14 Agustus 2018; disetujui: 01 September 2018

\begin{abstract}
Application of Problem Based Learning model to improve the learning outcomes proudly in the area where I live. Thesis study program of elementary school teacher education faculty teacher and education Pakuan Bogor Univercity 2018. This study with the design and model of Classroom Action Research (CAR) Conducted Collaboratively Between Researchess and observer and the subject studied. The purpose proud subtheme learning outcomes to my area of reasidence in grade 4 through the application of Problem Based Learning model. The subject of this research is the 4th grader of the public elementary school 01 Nagrak Gunung Putri district of Bogor Consisting of 39 students the implementation of this research is carried 2017/2018. The results showed that the average value of the learning process assessment in the cycle I of 78,25, cycle II 83,5 and the cycle III 90 with success indicators that is 81 , observation cycle I of 60,9 , cycle II 76,09 and cycle III 93,17 achievement indicator that is 81 . Completeness of students learning result cycle I reach $36 \%$, cycle II $64,11 \%$ and cycle III equal to $92 \%$ indicator of success $75 \%$ KKM value 75 based on the results of this studies, it can be concluded that the application of problem based learning model can improve the process of learning process and improve learning outcomes on proud subtema to my residence in grade 4 student of the public elementary school 01 Nagrak Gunung Putri district of bogor in the even semester of the academic year 2017/2018.
\end{abstract}

Keywords: Learning Outcomes, Problem Based Learning model, the learning outcomes proudly in the area where I live

\section{PENDAHULUAN}

Guru menjadi pengantar bagi siswa untuk menjalani kegiatan sehari-hari. Penerapan model pembelajaran menjadi salah satu cara agar melatih siswa mengolah pikirannya. Model Problem Based Learning yakni model pembelajaran yang mengaitkan pada pengembangan dalam penyelesaian masalah.

Subtema bangga terhadap daerah tempat tinggalku yang berkaitan dengan tempat tinggal makhluk hidup serta lingkungan sekitar memberikan pengetahuan dan sikap sosial yang dapat diambil dari setiap permasalahan. Subtema ini menggabungkan mata pelajaran Matematika, Bahasa Indonesia, Ilmu Pengetahuan Alam, Ilmu pengetahuan Sosial, Pendidikan Pancasila dan Kewarganegaraan, Seni, Budaya, dan Prakarya, Jasmani, Olahraga, dan Kesehatan disekolah untuk melatih kemampuan siswa dalam penyelesaian masalah. Dengan demikian siswa membutuhkan pola belajar yang membuat siswa lebih aktif, kreatif, mandiri dan dapat menjawab pertanyaan dengan tepat.

Melalui hasil observasi pra penelitian pada wali kelas IV SDN 01 Nagrak terungkap bahwa hasil belajar pada siswa kelas IV tidak stabil dikarenakan siswa masih sangat bergantung kepada guru sedangkan kurikulum 2013 mencanangkan seluruh kegiatan pembelajaran berpusat pada siswa. Berdasarkan rekapitulasi nilai ulangan, nilai semester, dan keterampilan pada subtema bangga terhadap daerah tempat tinggalku yang didapat dari wali kelas IV SDN 01 Nagrak, dengan jumlah siswa sebanyak 34 siswa diketahui rata-rata nilai aspek spiritual (KI-1) yaitu "sudah terlihat kebiasaan berdoa, bersyukur, beribadah, dan toleransi" adalah predikat "baik", rata-rata deskripsi nilai aspek sosial
(KI-2) yaitu "mulai terlihat, kerjasama, rasa ingin tahu dan tanggung jawab" adalah predikat "cukup baik". Aspek pengetahuan (KI-3) yaitu dari 34 terdapat siswa yang belum mencapai KKM sebesar 75. Jumlah siswa yang dibawah ketuntasan kriteria minimum sebesar 28 siswa atau $82,35 \%$ sedangkan 6 siswa atau 17,6\% siswa sudah mencapai kriteria ketuntasan minimal dan KI-4 yaitu dengan predikat "cukup baik".

Ketidakberhasilan dalam proses pembelajaran secara keseluruhan dikarenakan proses belajar mengajar yang membosankan, membuat siswa jenuh, dan ketergantungan siswa kepada guru. Ketergantungan ini diakibatkan karena guru masih menggunakan metode ceramah, sehingga siswa selalu dituntut untuk mendengarkan materi tanpa ikut serta dalam pembelajaran dan guru belum menerapkan model model pembelajaran yang menyenangkan untuk membuat siswa lebih aktif, kreatif, dan mandiri dalam belajar.

Salah satu solusi untuk mengiringi perubahan yang semula berpusat pada guru beralih berpusat pada siswa adalah ditemukannya dan diterapkannya model pembelajaran yang inovatif, kreatif dan konstruktif atau lebih tepat dalam mengembangkan dan menggali siswa untuk berfikir lebih kongkrit dan mandiri. Melalui pendekatan saintifik dengan model pembelajaran berbasis masalah (Problem Based learning) sangat cocok digunakan untuk menyelesaikan masalah tersebut karena pada model tersebut siswa diajak untuk belajar berkelompok untuk menyelesaikan suatu masalah dan mengemukakannya sehingga membuat siswa lebih aktif, mandiri dan percaya diri.

Berdasarkan pada latar belakang diatas peneliti tertarik untuk melakukan kegiatan penelitian mengenai 
Penerapan model problem based learning untuk memperbaiki hasil belajar pada subtema bangga terhadap daerah tempat tinggalku dikelas IV Sekolah Dasar Negeri 01 Nagrak Kecamatan Gunung Putri Kabupaten Bogor Semester Genap 2017/2018.

Berdasarkan latar belakang masalah di atas maka dapat dirumuskan masalah:

1. Bagaimana perbaikan proses pembelajaran pada subtema "Bangga Terhadap Daerah Tempat Tinggalku" dengan model Problem Based Learning di kelas IV Sekolah Dasar Negeri 01 Nagrak Kecamatan Gunung Putri Kabupaten Bogor semester Genap

2. Tahun Pelajaran 2017/2018. Apakah model Problem Based Learning dapat meningkatkan hasil belajar pada subtema "Bangga Terhadap Daerah Tempat Tinggalku" dikelas IV Sekolah Dasar Negeri 01 Nagrak Kecamatan Gunung Putri Kabupaten Bogor semester Genap Tahun Pelajaran 2017/2018.

\section{Hasil Belajar}

Hasil belajar adalah perubahan perilaku yang terjadi karena adanya belajar atau pengalaman yang didapat siswa baik diluar kelas maupun didalam kelas. Hasil belajar yang dicapai mencakup ranah kognitif (kecerdasan otak), ranah afektif (sikap) dan ranah psikomotorik (keterampilan).

Ranah kognitif adalah adalah hasil belajar siswa yang berkenaan dengan intelektual dan kecerdasan otak yang terdapat dalam diri siswa. tidak hanya ranah kognitif dalam hasil belajar juga ditemui ranah afektif dan psikomotorik. Ranah afektif adalah pola tindakan siswa yang merespons stimulus tertentu. Sikap berhubungan dengan nalar, nilai, penghargaan, dan pendapat siswa dalam proses pembelajara. Ranah psikomotorik adalah berkenaan dengan kemampuan hasil belajar dalam keterampilan bertindak yang terdapat pada diri siswa.

Hasil belajar bukan hanya berupa perubahan perilaku melainkan adanya perubahan kemampuan pada diri siswa dalam mengembangkan kreativitas. Hasil belajar dapat menjadi acuan untuk mencapai target siswa dalam belajar dan menjadi pendorong yang sangat baik dalam proses belajar siswa untuk mendapatkan hasil belajar yang ingin dicapai.

Pengertian tersebut selaras dengan pemikiran [1], [2] dan [3] yang mengemukakan bahwa hasil belajar adalah perubahan siswa baik perilaku maupun kemampuan yang mencakup ranah kognitif, ranah afektif dan ranah psikomotorik. Perubahan perilaku dan kemampuan siswa diperoleh karena adanya proses belajar mengajar yang melibatkan interaksi antar sumber belajar dengan lingkungan belajar.

Hasil belajar identik dengan perubahan perilaku siswa yang mencakup pada ranah kognitif, ranah afektif dan ranah psikomotorik siswa namun pendapat tersebut tidak selaras dengan pendapat [4] dan [5] yang mengemukakan bahwa hasil belajar adalah perubahan perilaku siswa yang tidak hanya mencakup ranah kognitif, ranah afektif dan ranah psikomotorik siswa melainkan perubahan perilaku itu mencakup segala ranah kemanusiaan yang didapatkan dari proses belajar siswa dan pengalamannya.

Keberhasilan siswa dalam belajar tidak hanya dipengaruhi oleh pribadi siswa tersebut melainkan dipengaruhi oleh faktor-faktor yang mendukung siswa dalam proses belajar mengajar. Banyak faktor yang menjadi pendukung siswa untuk mencapai keberhasilan yang didapat siswa salah satunya adalah faktor keluarga. Keluarga menjadi peranan yang sangat penting dalam peningkatan hasil belajar untuk mencapai keberhasilan siswa dalam belajar, keluarga yang hangat dan harmonis menjadikan siswa memiliki kepribadian yang hangat juga seperti saat proses belajar mengajar siswa yang hangat dapat menerima pelajaran dari guru secara baik sehingga siswa tersebut dapat mencapai hasil belajar yang baik pula. Tidak hanya keluarga yang menjadi faktor keberhasilan siswa dalam belajar banyak faktor lain yang mempengaruhi hasil belajar siswa seperti:

Faktor dari dalam siswa yang sangat mendukung siswa dalam belajar, jika tidak ada acuan dari dalam diri siswa untuk belajar maka siswa tersebut akan kesulitan saat menerima pelajaran yang guru berikan dan menjadikan siswa mendapatkan hasil belajar yang kurang baik pula.

Faktor dari luar diri siswa seperti keluarga, masyarakat dan teman sebaya menjadi faktor yang mendukung keberhasilan siswa dalam belajar karena lingkungan memiliki peran yang aktif untuk perkembangan siswa dalam berpikir maupun bersosialisasi.

Hal ini didukung oleh teori yang dikemukakan [6], [7], [8] dan [9] yang mengemukakan bahwa faktor yang mempengaruhi hasil belajar siswa adalah minat siswa, motivasi diri, bakat siswa, kondisi tubuh siswa, tingkat kecerdasan, faktor keluarga, lingkungan sekolah dan lingkungan masyrakat, faktor Instrumental

Pendapat mengenai faktor yang meningkatkan hasil belajar juga dikemukakan oleh [10] proses belajar siswa yang sangat dipengaruhi oleh emosi, apabila siswa merasa terpaksa dalam mengikuti suatu pelajaran maka siswa pun akan kesulitan menerima seluruh materi yang disampaikan guru dan hasil belajar siswa akan rendah maka dari itu guru harus dapat membuat inovasi baru untuk menciptakan kondisi kelas yang kondusif agar pembelajaran menyenangkan. Perlu adanya perubahan belajar dengan menggunakan model pembelajaran, strategi maupun metode.

\section{Model Problem Based Learning}

Perubahan cara pandang terhadap siswa sebagai objek menjadi subjek dalam proses pembelajaran menjadi titik tolak banyak ditemukannya berbagai pendekatan pembelajaran yang inovatif. Pada hakikatnya dalam pembelajaran adalah bagaimana belajarnya siswa dan bukan bagaimana mengajarnya guru.

Guru dituntut dapat memilih model pembelajaran yang dapat memacu semangat siswa untuk aktif dan ikut serta terlibat dalam proses pembelajaran. Salah satu alternatif model pembelajaran yang menjadikan siswa untuk mengembangkan keterampilan dan berpikir siswa secara 
nalar, komunikasi maupun koneksi adalah model problem based learning atau model pembelajaran berbasis masalah.

Model problem based learning adalah model yang mengajak siswa untuk berpikir logis dan luas dalam memecahkan masalah yang guru berikan. Model ini dapat mengurangi ketergantungan siswa kepada guru, karena pada model ini mengharuskan siswa untuk bekerja secara mandiri dalam memecahkan masalah.Dalam pemecahan masalah terdapat langkah-langkah atau metode ilmiah yang menjadikan siswa lebih kreatif dalam mengembangkan pemikirannya sendiri.

Pengertian tersebut selaras dengan pemikiran [11], [12], dan [13] yang menyatakan bahwa model problem based learning dapat dikembangkan jika melalui tahap-tahap metode ilmiah yang sesuai, sehingga siswa dapat mempelajari pengetahuan dengan masalah tersebut. Pendapat ini didukung oleh [14] yang mengemukakan bahwa problem based learning adalah model pembelajaran yang mengajak siswa untuk memecahkan masalah pembelajaran, tidak hanya memecahkan siswa juga diajak untuk mencari solusi untuk mengemukakan hasilnya.

Model problem based learning membantu siswa untuk mengembangkan kretaivitas berpikir tingkat tinggi penjelasan tersebut sama halnya dengan pendapat yang dikemukakan oleh [15] yang mengatakan bahwa problem based learning sangat efektif digunakan untuk proses pembelajaran berpikir tingkat tinggi yang disesuaikan oleh tingkat kognitif siswa saja sedangkan tingkat afektif dan tingkat psikomotorik siswa tidak diikut sertakan.

Dalam pelakasanaan model problem based learning diawali dengan tujuan pembelajaran, pemberian masalah, mengumpulkan informasi, strategi pemecahan masalah dan laporan dari hasil pemecahan masalah.

Terlihat dalam langkah-langkah yang dikemukakan oleh [16], [17] dan [10] yaitu sebagai berikut:

1. Guru menjelaskan tujuan pembelajaran agar memotivasi siswa terlibat langsung dalam aktivitas pemecahan masalah.

2. Guru membantu siswa mengorganisasikan tugas belajar yang berkaitan dengan masalah tersebut

3. Guru mengajak siswa untuk mengumpulkan informasi yang berkaitan dengan masalah tersebut

4. Setelah melakukan kegiatan pemecahan masalah, guru meminta siswa membuat hasil pekerjaannya melalui laporan.

5. Guru membantu siswa untuk melakukan refleksi dan evaluasi

Langkah-langkah dalam kegiatan model problem based learningselanjutnya dikemukakan oleh [12] dan [18] yaitu sebagai berikut 1) mengklarifikasikan konsep yang belum jelas, 2) mendefinisikan permasalahan, 3) menganalisis permasalahan, 4) diskusi, 5) merumuskan tujuan belajar, 6) belajar mandiri, dan 7) evaluasi

\section{Subtema Bangga Terhadap Daerah Tempat Tinggalku}

Subtema bangga terhadap daerah tempat tinggalku merupakan tema 8 subtema 3 yang mengaitkan materi dengan daerah tempat tinggal.Tempat tinggal adalah dimana seseorang menetap untuk berteduh dan untuk mengawali segala aktivitas, tempat tinggal menjadi salah satu kebutuhan pokok manusia.Tempat tinggal biasanya berupa rumah maupun pemukiman.

Uraian di atas diperkuat dengan pendapat [19] yang menyatakan bahwa tempat tinggal adalah salah satu kebutuhan dasar manusia yang digunakan untuk berteduh maupun menetap dari keadaan alam, serta tempat melaksanakan hak dan kewajibannya dalam menjalani hidup.Tempat tinggal manusia biasanya berwujud rumah maupun pemukiman.

Tempat tinggal adalah keharusan yang dimiliki setiap orang menurut badan hukum karena tempat tinggal memiliki kedudukan tertentu. Tempat tinggal dibedakan menjadi 2 yaitu:

1. Tempat tinggal yang sesungguhnya.

2. Tempat tinggal yang dipilih.

Berdasarkan kajian teoritik di atas maka dapat disintesiskan bahwa tempat tinggal pada subtema bangga terhadap daerah tempat tinggalku adalah salah satu kebiutuhan dasar manusia yang digunakan untuk menetap dan berteduh serta menjadi keharusan bagi setiap orang untuk memilki tempat tinggal karena memiliki kedudukan tertentu menurut badan hukum.

\section{METODE PENELITIAN}

\section{A. Rancangan Penelitian}

Penelitian dilaksanakan dengan pendekatan penelitian tindakan kelas melalui rancangan penelitian sebagai berikut:

\section{Tempat Penelitian}

Penelitian dilaksanakan di Sekolah Dasar Negeri 01 Nagrak Kecamatan Gunung Putri Kabupaten Bogor Semester Genap Tahun Pelajaran 2017/2018.

2. Waktu Penelitian

Penelitian dilaksanakan pada semester genap tahun pelajaran 2017/2018.

Tabel 1. Waktu Penelitian

\begin{tabular}{lllll}
\hline No & Hari/Tanggal & Waktu & $\begin{array}{l}\text { Acara } \\
\text { Tindakan }\end{array}$ & Keterangan \\
\hline 1 & 17 Oktober 2017 & $08.00-09.00$ & Prapenelitian & $\begin{array}{l}\text { Sumber data/ } \\
\text { fakta dari guru } \\
\text { kelas }\end{array}$ \\
\hline 2 & 09 April 2018 & $08.00-09.30$ & siklus I & $\begin{array}{l}\text { Kolaborator I } \\
\text { dan II }\end{array}$ \\
\hline 3 & 11 April 2018 & $08.00-09.30$ & siklus II & $\begin{array}{l}\text { Kolaborator I } \\
\text { dan II }\end{array}$ \\
\hline 4 & 16 April 2018 & $08.00-09.30$ & siklus III & $\begin{array}{l}\text { Kolaborator I } \\
\text { dan II }\end{array}$ \\
\hline
\end{tabular}

\section{B. Disain dan Mekanisme PTK}

\section{Perencanaan Tindakan (planning)}

Perencanaan tindakan (planning) adalah menyusun perangkat pembelajaran sesuai dengan materi yang akan diajarkan dan instrumen pengumpulan data yang diperlukan. 
2. Pelaksanaan Tindakan (acting)

Pelaksanaan tindakan (acting) adalah melaksanakan tindakan reflektif (pembelajaran) sesuai dengan RPP oleh guru atau peneliti.

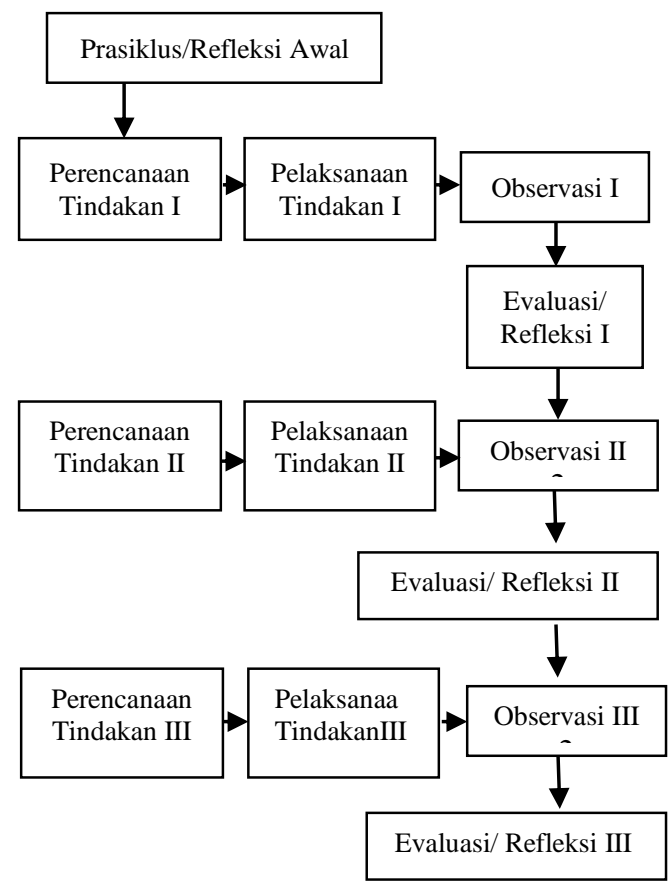

Gambar 1. Disain dan Mekanisme PTK

3. Observasi (observing)

Observasi adalah pengamatan selama berlangsungnya kegiatan pembelajaran oleh kolaborator dan/atau observer. Kegiatan observasi berlangsung secara simultan dengan kegiatan pelaksanaan tindakan reflektif.

4. Refleksi (reflecting)

Refleksi adalah mengevaluasi hasil analisis data penelitian untuk direkomendasikan. Kedua kolaborator bersamaguru/peneliti merekomendasikan aspek/indikator yang perlu diperbaiki pada siklus berikutnya, bila indikator keberhasilan penelitian belum berhasil.

\section{Prosedur Penelitian Tindakan Kelas}

Berdasarkan penelitian tersebut, dapat menunjang penelitian yang akan dilakukan oleh peneliti dengan judul Penerapan Model Problem Based Learning Untuk Meningkatkan Hasil Belajar pada subtema bangga terhadap daerah tempat tinggalku,

\section{Teknik Pengumpulan Data}

1) Observasi

a) Penilaian pelaksanaan proses pembelajaran di kelas

b) Perubahan perilaku siswa setelah dilakukan tindakan perbaikan

2) Tes

Tes dilakukan secara tertulis menggunakan butir soal untuk mengetahui sejauh mana hasil belajar siswa. Tes/penilaian dilakukan untuk melihat keberhasilan belajar siswa dengan mengacu pada KKM dan indikator yang telah di capai.

3) Studi Dokumentasi

Melakukan studi dokumentasi terhadap data-data yang dimiliki sekolah dan guru.

\section{E. Instrumen Pengumpulan Data}

Instrumen Perbaikan Proses Pembelajaran dalam penelitian ini bertujuan untuk memperoleh data tentang memperbaiki hasil belajar subtema bangga terhadap daerah tempat tinggalku dengan model Problem Based Learning. Berdasarkan tujuan itu maka ada tiga jenis instrumen yang diperlukan, yaitu:

1) Instrumen Penilaian Pelaksanaan Proses Pembelajaran di Kelas

2) Lembar Observasi Perilaku Siswa Setelah Di Berikan Tindakan

3) Lembar Observasi Keterampilan Siswa Setelah Di Berikan Tindakan.

\section{F. Indikator Keberhasilan Penelitian}

Indikator keberhasilan peneliti ini ditentukan oleh peneliti dengan tim kolaborator dengan menitik beratkan pada dua aspek proses (81) dan hasil (81). Indikator keberhasilan proses dilihat dari kinerja profesional guru dalam menerapkan model Problem Based Learning pada subtema bangga terhadap daerah tempat tinggalku. Partisipasi siswa dalam proses pembelajaran dan perkembangan hasil belajar siswa memunculkan sikap-sikap positif dari siswa selama pembelajaran.

\section{G. Interpretasi Data}

\begin{tabular}{lll}
\hline Konversi Nilai & Kategori & Interpretasi \\
\hline $81-100$ & A & Sangat baik \\
\hline $61-80$ & B & Baik \\
\hline $41-60$ & C & Cukup \\
\hline $21-40$ & D & Kurang \\
\hline $0-20$ & E & Sangat kurang baik \\
\hline
\end{tabular}

\section{H. Tim Kolaborasi}

Tim kolaborasi terdiri dari dua orang guru atau pendidik yang berasal dari sekolah tempat penelitian. Anggota tim kolaborasi disebut kolaborator atau observer yang bertugas memberi penilaian terhadap pelaksanaan pembelajaran dan mengobservasi prilaku siswa. Data observer dalam penelitian ini diantaranya:
1. Nama
Jabatan : Guru kelas II
2. Nama : Eva Apriyani, S. Pd
Jabatan : Guru kelas V

\section{HASIL DAN PEMBAHASAN}

Peningkatan yang terjadi pada kualitas pembelajaran, perubahan sikap, perubahan prilaku, serta hasil belajar siswa telah mencapai indikator keberhasilan minimal yang 
ditetapkan. Hal tersebut merupakan keberhasilan peneliti dalam menerapkan model problem based learning pada subtema bangga terhadap daerah tempat tinggalku, sehingga tidak diperlukan perbaikan pada siklus selanjutnya dan penelitian dapat diakhiri dengan tiga siklus.

Untuk mengetahui peningkatan hasil penelitian pada siklus I, siklus II, dan siklus III maka dibuatkan rekapitulasi hasil penelitian seperti tampak pada tabel 2 .

Tabel 2. Rekapitulasi Hasil Penelitian

\begin{tabular}{|c|c|c|c|c|}
\hline \multirow{2}{*}{ Aspek } & \multicolumn{3}{|c|}{ Hasil siklus } & \multirow{2}{*}{$\begin{array}{c}\text { Indikator } \\
\text { Keberhasilan }\end{array}$} \\
\hline & I & II & III & \\
\hline $\begin{array}{l}\text { Kualitas } \\
\text { Pembelajaran }\end{array}$ & $\begin{array}{l}78,25 \\
\text { Baik }\end{array}$ & $\begin{array}{l}83.5 \\
\text { Sangat } \\
\text { Baik }\end{array}$ & $\begin{array}{l}90 \\
\text { Sangat } \\
\text { Baik }\end{array}$ & 81 \\
\hline $\begin{array}{l}\text { Sikap Sosial } \\
\text { Siswa }\end{array}$ & $\begin{array}{l}65 \\
\text { Baik }\end{array}$ & $\begin{array}{l}79.3 \\
\text { Baik }\end{array}$ & $\begin{array}{l}86.16 \\
\text { Sangat } \\
\text { Baik }\end{array}$ & 81 \\
\hline $\begin{array}{l}\text { Ketuntasan } \\
\text { Hasil Belajar }\end{array}$ & $36 \%$ & $\begin{array}{l}64,11 \\
\%\end{array}$ & $92 \%$ & 75 \\
\hline $\begin{array}{l}\text { Keterampilan } \\
\text { (proyek } \\
\text { dan Praktik) }\end{array}$ & $\begin{array}{l}60.9 \\
\text { Baik }\end{array}$ & $\begin{array}{l}76.09 \\
\text { Baik }\end{array}$ & $\begin{array}{l}93.17 \\
\text { Sangat } \\
\text { Baik }\end{array}$ & 81 \\
\hline Nilai rata-rata & $\begin{array}{l}67 \\
\text { Baik }\end{array}$ & $\begin{array}{l}74,57 \\
\text { Baik }\end{array}$ & $\begin{array}{l}81,3 \\
\text { Sangat } \\
\text { Baik }\end{array}$ & 75 \\
\hline
\end{tabular}

Berdasarkan tabel 2 dapat dilihat bahwa peningkatan proses pembelajaran siklus I mencapai $78,25 \%$ dengan kualifikasi cukup, namun untuk lebih meningkatkan dilakukannya siklus II mencapai 83,5 \% dengan kualifikasi baik, namun untuk lebih meningkatkan proses pembelajaran dilakukannya siklus III mencapai $90 \%$ dengan kualifikasi sangat baik. Menunjukan bahwa terdapat peningkatan pada penelitian tindakan kelas ini.

Selain hasil pengamatan proses pembelajaran dikelas, peneliti juga melaksanakan pengamatan sikap sosial siswa dan keterampilan (proyek maupun praktik) selama proses pembelajaran berlangsung pada siklus I. Nilai hasil pengamatan observasi sikap siswa pada tindakan siklus I oleh observer maupun kolaborator memperoleh 65 dengan kualifikasi cukup dan pengamatan keterampilan (proyek dan praktik) pada siklus I memperoleh 64.09 maka penelitian tindakan kelas dengan penerapan model problem based learning pada siswa kelas IV A SDN 01 Nagrak dilanjutkan pada siklus berikutnya yaitu siklus II. Pada siklus II perubahan sikap siswa dan keterampilan siswa mengalami peningkatan dengan memperoleh hasil 76.09 pada observasi sikap 79.3 dan pada keterampilan (proyek dan praktik) namun peningkatan tersebut belum mencapai indikator ketuntasan sebesar 81 maka penelitian tindakan kelas dengan penerapan model problem based learning pada siswa kelas IV A SDN 01 Nagrak Kecamatan Gunung Putri Kabupaten Bogor dilanjutkan pada siklus berikutnya yaitu siklus III. Pada siklus III terjadi peningkatan yang signifikan pada observasi sikap dan keterampilan (proyek dan praktik).Pada observasi sikap siklus III memperoleh 86.16 dan keterampilan (proyek maupun praktik) memperoleh 93.7.Hal ini menandakan bahwa hasil observasi sikap dan keteramapilan (proyek dan praktik) dalam siklus III mengalami peningkatan dan mencapai indikator pencapaian sebesar 81 .
Hasil belajar siswa pada siklus I diperoleh jumlah keseluruhan siswa sebesar $35,89 \%$ dengan nilai rata-rata 66,9. Nilai tertinggi 78 dan nilai terendah 43. Dari hasil belajar tersebut jumlah siswa yang mencapai KKM sebanyak 14 siswa atau $35,89 \%$. Hal ini berarti masih banyaknya siswa yang belum mencapai KKM sebanyak 25 siswa atau 64,11\% dengan KKM yang sudah ditentukan sebesar 75 .

Pencapaian keberhasilan ideal kelas ditentukan minimal 75\%. Dengan meningkatkan proses pelaksanaan pembelajaran yang mengacu pada penerapan model problem based learning dikelas IV A SDN 01 Nagrak Kecamatan Gunung Putri Kabupaten Bogor. dilaksanakannya penelitian tindakan kelas siklus II untuk meningkatkan hasil belajar siswa dan mencapai KKM yang sudah ditentukan.

Pada siklus II diketahui jumlah nilai keseluruhan siswa dengan rata-rata 74,57 dengan nilai tertinggi 83 dan nilai trendah 66. Dari hasil belajar tersebut jumlah siswa yang mencapai KKM 75 sebanyak 25 siswa atau $64,11 \%$ dan jumlah siswa yang belum mencapai KKM sebanya 14 siswa atau $35,89 \%$. Meskipun pada siklus II jumlah siswa yang mencapai KKM sebanyak 25 siswa ata $64,11 \%$ namun pada siklus II ini indikator hasil pencapaian secara klasikal belum terwujud sebesar $80 \%$.

Berdasarkan hasil siklus II maka untuk lebih meningkatkan hasil belajar siswa dilakukannya siklus berikutnya yaitu siklus III.Pada siklus III nilai rata-rata siswa sebesar 81,3 dengan nilai tertinggi sebesar 96 dan nilai terendah 68. Dari data hasil belajar tersebut 36 siswa atau $92 \%$ sudah mencapai KKM sebesar 75 dan 3 atau $8 \%$ siswa belum mencapai KKM. Dengan demikian indikator pencapaian klasikal pada siklus III sudah tercapai sebesar $92 \%$.

Peningkatan hasil belajar siswa pada penelitian tindakan kelas kali ini tidak terlepas dari peran guru dalam proses pembelajaran dan beberapa faktor yang terdapat pada diri siswa dalam pelaksanan proses pembelajaran. bahwa proses belajar siswa yang sangat dipengaruhi oleh emosi, apabila siswa merasa terpaksa dalam mengikuti suatu pelajaran maka siswa pun akan kesulitan menerima seluruh materi yang disampaikan guru dan hasil belajar siswa akan rendah maka dari itu guru harus dapat membuat inovasi baru untuk menciptakan kondisi kelas yang kondusif agar pembelajaran menyenangkan. Salah satu inovasi yang menjadi faktor peningkatan hasil belajara adalah perlu adanya perubahan belajar dengan menggunakan model pembelajaran, strategi maupun metode.

Pendapat lain dikemukakan oleh [19] yang mengatakan bahwa faktor yang mempengaruhi hasil belajar hanya terdapat dari dalam diri siswa dan guru seperti :

1. Bagi guru
a. Kesiapan guru dalam mengajar
b. Penguasaan guru terhadap materi pelajaran
c. Kemampuan bawaan guru
d. Kemampuan guru dalam berkomunikasi

2. Bagi siswa

a. Kesiapan siswa dalam belajar

b. Sikap belajar siswa 
c. Ada atu tidaknya kesulitan belajar yang dialami siswa pada umumnya.

Pendapat ini didukung oleh [10] yang mengatakan bahwa guru harus memiliki empat hal yang harus dikuasai yaitu menguasai bahan pelajaran, mampun mendiagnosis tingkah laku siswa, mampu melaksanakan proses pembelajaran dan mampu mengevaluasi hasil belajar siswa.

Pendapat lain dikemukakan oleh [2], [16], [6] dan [7] yang mengemukakan bahwa faktor yang mempengaruhi hasil belajar siswa adalah minat siswa, motivasi diri, bakat siswa, kondisi tubuh, tingkat kecerdasan, faktor keluarga, lingkungan sekolah dan masyarakat.

Peningkatan hasil belajar yang telah dikemukakan diatas tidak terlepas dari penggunaan model pembelajaran yang menyenangkan. Hal tersebut didukung oleh [8] yang mengatakan bahwa guru harus bisa memilih model pembelajaran yang dapat memacu semangat siswa untuk terlibat dalam proses pembelajaran. Salah satu alternatifnya adalah dengan penerapan model problem based learning yang dapat mengembangkan keterampilan berpikir siswa dalam memecahkan masalah. Pendapat ini didukung oleh [9] yang mengemukakan bahwa problem based learning adalah model pembelajaran yang mengajak siswa untuk memecahkan masalah pembelajaran, tidak hanya memecahkan siswa juga diajak untuk mencari solusi untuk mengemukakan hasilnya. Model problem based learning juga memiliki kelebihan yaitu yang dikemukakan oleh [16], [20], [17], dan [10] mengatakan bahwa kelebihan model problem based learning adalah :

1. Mengembangkan pemikiran kritis dan keterampilan kreatif mandiri

2. Meningkatkan motivasi dan kemampuan memecahkan masalah

3. Terjadi penalaran yang sangat bermakna.

4. Meningkatkan kemampuan siswa untuk berpikir kritis.

Hasil penelitian dan pembahasan di atas didukung oleh penelitian yang dilakukan oleh Siti Mariatul NPM 135060030 Fakultas Keguruan dan Ilmu Pendidikan Universitas Pasundandengan judul "Penerapan Model Problem Based Learning untuk meningkatkan hasil belajar siswa pada tema 9 kayanya negeriku" penelitian ini dilakukan untuk meningkatkan sikap dan hasil belajar pada Subtema 1 kekayaan Sumber Energi di Indonesia di SDN Cicalengka 08 khususnya di kelas IV A dengan menerapkan model Problem Based learning (PBL). Dari hasil dan pembahasan diperoleh beberapa kesimpulan Pertama, adanya peningkatan pelaksanaan pembelajaran pada siklus I $67 \%$, pada siklus II $74 \%$ dan di siklus III menjadi $91,5 \%$. Kedua adanya peningkatan sikap percaya diri siklus I 20,6\%, siklus II $50 \%$ dan siklus III $82 \%$. Ketiga adanya peningkatan sikap peduli siklus I 23\%, siklus II 53\% dan siklus III $79 \%$. Keempat adanya peningkatan sikap tanggungjawab siklus I $34 \%$, siklus II 55\% dan siklus III meningkat menjadi $81 \%$.

Hasil penelitian dan pembahasan tersebut didukung pula oleh Yuni Purwanti NIM 135060285. Fakultas Keguruan dan Ilmu Pendidikan Universitas Pasundandengan judul "Penerapan model pembelajaran Problem Based Learning untuk meningkatkan hasil belajar siswa pada subtema kekayaan sumber energy di Indonesia".Penelitian ini dilaksanakan dikelas IV SD Negeri Cicalengka 05 Kabupaten BandungHasil yang diperoleh siklus I menunjukan sikap percaya diri diatas KKM yaitu 43,3\%, sedangkan sikap peduli yang memiiki nilai diatas KKM hanya $46,7 \%$, dan sikap tanggungjawab siswa diatas KKM hanya $50 \%$. Hasil tersebut tidak jauh berbeda dengan nilai pemahaman yaitu $46,7 \%$ dan keterampilan $53,3 \%$ yang mendapat nilai diatas KKM. Sedangkan hasil yang diperoleh pada siklus II menunjukan hasil sikap percaya diri 56,7\%, sikap peduli 53,3\%, sikap tanggung jawab 60\%, nilai pemahaman siswa $60 \%$ dan nilai keterampilan siswa $63 \%$. Hasil belajar siklus III diantaranya pada ranah afektif yaitu nilai sikap percaya diri yaitu $83,3 \%$, sikap pdeuli mencapai $80 \%$ dan sikap tanggungjawab $86,7 \%$ yang mencapai nilai diatas KKM. Nilai kognitif atau pemahaman siswa yang mendapat nilai diatas KKM mencapai $83,3 \%$, dan nilai keterampilan berkomunikasi atau psikomotorik siswa mencapai $80 \%$. Berdasarkan data tersebut, maka dapat disimpulkan dengan penggunaan model Problem Based Learning dapat meningkatkan hasil belajar siswa pada subtema Kekayaan Sumber Energi di Indonesia dikelas IV SDN Cicalengka 05.Berdasarkan data-data yang diperoleh tersebut terdapat beberapa perbedaan yaitu penelitian lebih baik daripada penelitian yang relevan berdasarkan data-data yang diperoleh pada saat pembelajaran berlangsung.

\section{SIMPULAN}

Berdasarkan pembahasan hasil penelitian yang telah dilakukan, dapat disimpulkan bahwa:

1. Penerapan model pembelajaran problem based learning dapat memperbaiki proses pembelajaran pada subtema bangga terhadap daerah tempat tinggalku di kelas IV SDN 01 Nagrak Kecamatan Gunung Putri Kabupaten Bogor Semester Genap Tahun pelajaran 2017/2018.

2. Penerapan Model Problem Based Learning dapat meningkatkan hasil belajar siswa subtema bangga terhadap daerah tempat tinggalku pada subtema bangga terhadap daerah tempat tinggalku di kelas IV SDN 01 Nagrak Kecamatan Gunung Putri Kabupaten Bogor Semester Genap Tahun pelajaran 2017/2018.

\section{REFERENSI}

[1] Jihad, Asep dan Abdul Haris. Evaluasi Pembelajaran. Yogyakarta: Multi Pressindo. 2013.

[2] Kunandar. Penilaian Autentik. Jakarta: Rajawali Pers. 2013.

[3] Rusmono. Strategi Pembelajaran dengan Problem Based Learning. Ciawi: Graha Indonesia. 2012.

[4] Thobroni. Belajar dan Pembelajaran Teori dan Praktik. Yogyakarta: AR-RUZZ Media. 2017.

[5] Purwanto. Evaluasi Hasil Belajar. Yogyakarta: Pusaka Pelajar. 2011.

[6] Sudjana, Nana. Penilaian Hasil Proses Belajar Mengajar. Bandung: PT Remaja Rosdakarya. 2016. 
[7] Munadi, Yudhi. Media Pembelajaran Sebuah Pendekatan Baru. Jakarta: Gaung Persada Pers. 2010.

[8] Tu'u, Tulus. Peran Disiplin Pada Perilaku dan Prestasi Siswa. Jakarta: PT Gramedia Widiasarana Indonesia. 2004.

[9] Slameto. Belajar dan Faktor-Faktor yang Mempengaruhi. Jakarta: PT Rineka Cipta. 2013.

[10] Shoimin, Aris. 68 Model Pembelajaran Inovatif dalam Kurikulum 2013. Yogyakarta. AR-RUZZ MEDIA. 2014.

[11] Fathurrohman, Muhammad. Paradigma Pembelajaran Kurikulum 2013. Yogyakarta: Kalimedia. 2015.

[12] Sani, Ridwan Abdullah. Pembelajaran Saintifik untuk Implementasi Kurikulum 2013. Jakarta: Bumi Aksara. 2015.

[13] Ngalimun. Strategi dan Model Pembelajaran. Yogyakarta. Aswaja Pressindo. 2016.

[14] Daryanto, Karim Syaiful. Pembelajaran Abad 21. Yogyakarta: Gava Media. 2016.

[15] Suprihatiningrum, Jami. Strategi Pembelajaran Teori dan Aplikasi. Jogjakarta: AR-RUZZ Media. 2016.

[16] Rusman. Model-model Pembelajaran Mengembangkan Profesionalisme Guru. Jakarta: PT Raja Grafindo Persada. 2011.

[17] Sanjaya, Wina. Strategi Pembelajaran Berorientasi Standar Proses Pendidikan. Jakarta: Kencana Prenadamedia Group. 2011.

[18] Huda, Miftahul. Model-model pengajaran dan pembelajaran. Yogyakarta: Pustaka Belajar. 2013.

[19] Koestoer, Raldi hendro. Perspektif Lingkungan Desa Kota. Jakarta: UI Press. 1997.

[20] Daryanto, Karim Syaiful. Pendekatan Pembelajaran Saintifik Kurikulum 2013. Yogyakarta: Gava Media. 2014. 